\title{
Atatürk Dönemi Türkiye - Irak İlişkileri
}

\author{
Turkey-Iraq Relations in Ataturk Period
}

Hüseyin SEVİNÇ

Dr. $\ddot{O} \breve{g r}$. Gör., Bitlis Eren Üniversitesi, Ahlat MYO,hsevinc@beu.edu.tr https://orcid.org/0000-0003-2037-6665
Makale Başvuru Tarihi: 20.02.2021

Makale Kabul Tarihi: 06.04.2021

Makale Türü: Araştırma Makalesi $\begin{aligned} & \text { Anahtar } \\ & \text { Kelimeler: }\end{aligned}$
Musul Sorunu,
Dış Politika,
Sadabat Paktı,

Keywords:

Mosul Question,

Foreing Policy,

Sa'dabad Pact,

\section{ÖZET}

Cumhuriyet döneminde Türkiye'nin temel dış politikası öncelikle olarak bağımsızlı̆̆ın sürdürülmesi ve milli menfaatlerin korunması temeline dayanıyordu. Bu politika çerçevesinde yürütülmesi gereken diplomasi, iyi komşuluk ilişkilerini geliştirmek ve dünya politikasında söz sahibi devletlerle işbirliğine gitmek şeklinde belirlenmiştir. Yeni dış politika belirlenirken özellikle Osmanlı'nın son dönemindeki gibi kendi coğrafyasında yalnız kalmamaya ve bu çerçevede kendisine karşı bir düşman bloğunun oluşmamasına özen gösterilmiştir. Atatürk'ün barış̧̧ıl dış politikası, komşularla iliş̧kilerde öncelikli olarak uygulanmaya başlanmıştır. Bu kapsamda komşu ülkelerle iyi ilişsiler kurulmasına özen gösterilmiştir. Türkiye, bu dönemde Ortadoğu ülkeleri ile münasebetlerini geliştirmeye çalışmıştır. Bu ilişkileri gelişstirirken barış̧̧ıl bir dış politika çerçevesinde komşu ülkeler ile dostane ilişkiler kurulmaya çalışılmıştır. Bu çalışmada Atatürk dönemi Türkiye-Irak ilişskileri; Irak'ın kuruluşu, Musul sorunu ve Sadabat Paktı çerçevesinde ele alınmıştır. Sadabat Paktı, beklenen sonuçları ortaya çıkaramamış olsa da Balkan Antantına benzer bir biçimde Türkiye'nin bölgesel bir aktör olabilmesi açısından dış politikada yaşanmış önemli bir gelişmedir.

\begin{abstract}
Main foreign policy of Turkey during the Republican era primarily relied on the basis of maintaining the independence and protection of national interests. The diplomacy that should be carried out within the framework of this policy is formed by developing good neighborly relations and cooperating with the states that have a say in world politics. Main concern of this foreingn policy is not to being alone in its own geography and not to let form enemy blocks against Turkey. Atatürk's peaceful foreign policy began to be implemented primarily in relations with neighbors and attention was paid to establishing good relations with neighboring countries. Turkey has tried to improve its relations with Middle Eastern countries during this period. While developing these relations, friendly relations were tried to be established within the framework of peaceful foreign policy. In this study Turkey-Iraq relations is discussed wihtin the framework of establidshment of Iraq, Mosul Question and Sa'dabad Pact. Although the Sadabat Pact failed to produce the expected results, it is an important foreign policy development in terms of Turkey becoming a regional actor, similar to the Balkan Pact.
\end{abstract}




\section{GIRISS}

Birinci Dünya Savaşının sona ermesi olan 1918 yılı ile İkinci Dünya Savaşının başlangıcı olan 1939 yılları arasında geçen zaman, Avrupa açısından uzun bir ateşkes dönemi olarak görülür. Bu dönemde Ortadoğu ise yeni gelişmelerin ve konumlanmanın yaşandığı bir odak haline gelmiştir. İki dünya savaşı arasındaki bu ara dönemde Ortadoğu, cerrahi müdahalelerin yaşandığı bir coğrafi alan olarak nitelendirilebilir. Bölgede İran ve Afganistan dışındaki devletler fiilen olmasa bile hukuken Osmanlı Devleti egemenliği altında bulunmaktaydı. Osmanlı Devleti'nin savaştan yenik çıkması ile birlikte bölgenin kontrolü İngiltere ve Fransa'nın eline geçmişti.

Milli Mücadele döneminin başladığı 1919 yılında Ortadoğu'da önemli gelişmeler yaşanmaktaydı. Hicaz'da dine dayalı Arap Krallığı girişimleri yaşanırken, Suriye'de bağımsızlık pazarlıkları ve Avrupalılarla silahlı çatışmalar devam etmekteydi. Lübnan'da çizilen keyfi sınırlar ve Hristiyan azınlığın Müslüman çoğunluğu yönetmesi nedeniyle ortaya çıkan huzursuzluklar söz konusu iken, Türkiye'de de bitmiş olan savaştan yeni bir savaşa girmenin oluşturduğu gerginlik yaşanmaktaydı. Afganistan, içinde bulunduğu İngiltere boyunduruğundan kurtulma mücadelesi verirken, İran'da İngiliz nüfusunun etkinliği söz konusuydu. Bu nedenle İran'da İngiliz etkisinde yarı bağımsız bir yönetsel yapı mevcuttu.

Milli Mücadele dönemi ve Lozan Antlaşması sonrasındaki Türkiye Ortadoğu ilişkilerini, Misak-1 Milli'de belirtilen amaçlar ve ilkeler doğrultusunda incelemek gerekir. Misak-1 Milli'nin temel ilkesi, Türk nüfusunun çoğunlukta olduğu yerlerde bir Türk Devleti kurmaktı (Gönlübol ve Sar, 1997:87). Bu temel ilke çerçevesinde Türkiye, varisi olduğu Osmanlı Devleti’nin egemenliği altındaki Arap ülkeleri üzerindeki iddialarından vazgeçmiş ve kendi amaçlarını başka milletlerin çıkarlarına dokunmayacak şekilde belirlemiş oluyordu (Koloğlu, 1994:43). Belirtilen amaç doğrultusunda Ortadoğu'da kurulan ülkeler ile ilişkilerin dostane bir şekilde devam etmemesi için hiçbir engel yoktu. Atatürk, belirlemiş olduğu barışçıl dış politika çerçevesinde Ortadoğu ülkeleriyle Milli Mücadele döneminde iyi ilişkiler kurmak istemiş ve hatta savaş sırasında bu ülkelerin desteğini de beklemişti.

Atatürk, Türkiye'nin verdiği mücadelenin sadece Türkiye ile sınırlı olmadığını, bu davanın aynı zamanda doğunun tüm mazlum milletlerinin de davası olduğunu belirtmiştir. $\mathrm{Bu}$ nedenle Atatürk, milli mücadeleyi yürütülürken aynı zamanda doğu milletlerini de bilinçlendirmeye çalışıyor ve onları emperyalizmle mücadeleye hazırlıyordu. Örneğin 15.06.1919 tarihinde Mustafa Kemal, Irak aşiret başkanı Uceymi Paşa'ya mektup göndererek onları ortak savaşa çağırmıştı (Sarıhan,1993:323-333). Atatürk 09.10.1919 tarihinde Halep'te yayınlanan bildirisiyle "Anadolu' yu kurtardıktan sonra Arapları da kurtaracă̆ını” bildirmişti.

Cumhuriyet döneminde ise Türkiye Cumhuriyeti'nin temel dış politikası, öncelikle bağımsızlığın sürdürülmesi ve milli menfaatlerin korunması temeline dayanıyordu. Belirlenen bu politika çerçevesinde yürütülmesi gereken diplomasi, iyi komşuluk ilişkilerini geliştirmek ve dünya politikasında söz sahibi olan devletler ile işbirliğine gitmek üzerine kurgulanmıştı. Yeni dış politika belirlenirken, Osmanlı'nın son döneminde kendi coğrafyasında yalnız kalması ve kendisine karşı bir düşman bloğunun oluşması durumundan ders alınmış ve yeni kurulan devlet için böyle bir tablonun oluşmaması amacıyla dış politikada özen gösterilmişti. Atatürk, bu bağlamda komşu devletler ile olan ilişkilerde barışçıl bir dış politika izleyerek, komşu devletler ile iyi ilişkiler kurulmasına öncelik vermişti (Kurat, 1975:265).

Milli mücadele sırasında ve Lozan sonrasında Ankara Hükümeti, Osmanlı egemenliği altında bulunan Ortadoğu ülkeleri üzerindeki haklarından vazgeçtiğini açıklamıştır. Bu nedenden dolayı Türkiye ile Ortadoğu ülkeleri arasında önemli bir çıkar çatışması söz konusu olmamıştır. Sadece güney sınırlarının belirlenmesinde Türkiye; Irak ve Suriye manda rejimleriyle zorunlu ilişkilere girmiştir. Lozan'da çözülemeyen Musul sorunu 1926 y1lında çözülmüş ve sonrasında Irak ile ilişkiler iyi yönde seyretmiştir. Türkiye bu dönemde Ortadoğu ülkeleri ile ilişkilerini geliştirmeye çalışmıştır. Bu ilişkileri geliştirirken bir yandan da barış̧̧ıl dış politikalar çerçevesinde Ortadoğu ülkeleri ile dostane ilişkiler kurulmaya çalışılmıştır.

$\mathrm{Bu}$ çalışmada Atatürk dönemi Türkiye-Irak ilişkileri; Irak devletinin kuruluşu ile kuruluş sürecinde ve sonrasında iki devlet arasındaki ilişkilerin temelini teşkil eden Musul Sorunu çerçevesinde incelenmiştir. Musul Sorunu'nun çözümden sonra gelişen olumlu ilişkiler ve bölgelesel gelişmeler ise Sadabad Paktı çerçevesinde ele alınmıştır. 


\section{IRAK'IN KURULUŞU}

Atatürk dönemi Türkiye Irak ilişkileri incelenirken öncelikle bağımsız bir Irak Devleti'nin varlığından söz etmenin mümkün olmadığını belirtmek gerekir. Irak Devleti 1930 yılında bağımsızlığını kazanmış, 1932 yılında Milletler Cemiyeti'ne üye olmuştur. Fakat uzun bir süre İngiliz denetiminden kurtulamamıştır. Bu nedenle Türkiye-Irak ilişkilerini, Türk-İngiliz ilişkilerinin bir parçası olarak ele alıp, değerlendirmek gerekmektedir (Koçsoy, 1991:1).

İngiltere sanayisinin ve askeri gücünün ihtiyacı olan petrol kaynaklarının Irak ve diğer Arap ülkelerinde bulunmas1 ve Irak'ın Bat1 Asya ile Hindistan'1 bağlayan güzergah üzerinde bulunmas1, İngiltere sanayisine hammadde temin edebilecek bir kaynak ve aynı zamanda sanayi ürünleri için bir pazar olarak görülmesi, İngiltere'nin bu topraklarda yer alma arzusunun temel nedenlerindendir (Şahin vd., 2014:106). Kısaca özetlemek gerekirse İngiltere, zengin petrol kaynaklarına sahip olan ve imparatorluk yolunu Akdeniz kıyılarından Basra Körfezine kadar birleştiren Irak’a tam egemen olmak istiyordu.

Irak devleti, Ortadoğu'daki diğer devletler gibi coğrafi, etnik, dini ve sosyolojik özellikler dikkate alınmaksızın sınırları çizilen, suni yapıdaki devletlerden birisidir (Kocaoğlu, 1995:86). Tarihte Irak devleti olarak adlandırılan bölgeye bakıldığında, etnik açıdan homojen olmayan ve birçok etnik unsuru içinde barındıran karışık bir yapı ile karşılaşılmaktadır. Osmanlı devleti döneminde Irak toprakları; Bağdat, Basra ve Musul eyaletleri olarak bölgelere ayrılmıştı. Bu bölgelerde de etnik, kültürel ve dinsel anlamda bir homojenlik söz konusu değildi. Daha yalın bir ifadeyle Irak devletinin kuruluş aşamasında herhangi bir objektif kriter esas alınmamıştı. Irak, emperyalist güçler tarafından, tamamen kendi çıkarları doğrultusunda oluşturulmuş suni yapıda bir devletti (Kocaoğlu, 1995:68).

Yukarıda yapılan açıklamalar doğrultusunda modern Irak Devleti, 1920 yılında Osmanlı devletinin Birinci Dünya Savaşı'nda yenilmesiyle birlikte, Osmanlı eyaletleri olan Musul, Bağdat ve Basra'nın İngiltere tarafından birleştirilmesi sonucu oluşturulmuştur. Bu yeni devlet Fırat ve Dicle Havzasını kontrolü altına alan ve yakın bir bölge devleti tarafından yönetilmeyen yeni bir siyasi oluşumdur. Tarih içinde bu coğrafyada daha önce yaşamış bir Irak devleti veya bir Irak halkı olmamıştır (Yapp, 1991:69-84).

Birinci dünya savaşı başladığında Osmanlı orduları özellikle Ortadoğu'da, Irak cephesinde İngilizlere karşı büyük mücadele vermişlerdir. Osmanlı Devleti Arap yarımadasında İngilizlerle savaşırken, aynı zamanda Arap milliyetçiliği çerçevesinde Avrupalı devletlere yanaşan Araplarla da mücadele etmek durumunda kalmışlardır. 1917 yılına kadar savunulan Bağdat, bu tarihte İngilizlere bırakılmıştır. Bu dönemde Mondros Ateşkes Anlaşması imzalandığında Osmanlı ordusunun elinde bulunan Musul, antlaşma hükümlerine aykırı olarak İngilizler tarafından işgal edilmiştir (Sarıhan, 1993:411).

Savaş sırasında 1916 yılında Mekke Emiri Şerif Hüseyin İngilizlerin kışkırtmasıyla Osmanlı Devleti’ne isyan etmiştir. Şerif Hüseyin ile oğullarına isyan neticesinde Büyük Arap Krallığı sözü verilmiştir. Bu süreçte Arap unsurlar isyana teşvik edilirken 1916 yılında Fransa ve İngiltere Sykes-Picot Anlaşması ile Ortadoğu topraklarını kendileri aralarında paylaşmışlardır. Savaş sonunda bu anlaşmanın gereği olarak, yapılan paylaşım hayata geçirildi. Anlaşmaya göre Suriye ve Lübnan Fransızlara; Irak, Ürdün ve Filistin toprakları da İngilizlere bırakılmıştı (Türkiye Cumhuriyet Tarihi II, 2002:411). Bu anlaşma ile Ortadoğu'da yeni yapay devletler kurulmuştur. Yeni kurulan ülkelerin sınırları çizilirken bölgenin etnik ve dinsel yapısı gözetilmemiştir. Dönemin iki büyük emperyalist gücü kendi çıkarları doğrultusunda etnik grupları da harita üzerinde oluşturdukları devletler sayesinde parçalamışlardır. İngiltere ile Fransa arasındaki gizli anlaşmadan haberi olmayan Şerif Hüseyin'in oğlu 1918 yılında Şam'a girerek Arap yönetimi kurmuştur. Toplanan Suriye Meclisi Lübnan ve Filistin'i de içine alarak Faysal'ın krallığı altında bağımsızlığını ilan etmiştir.

1920 yılında Sam Remo'da alınan kararlar doğrultusunda Sykes-Picot anlaşması yasal bir zemine oturtulmuştur. San Remo Konferansında, Irak'a yerleşmiş olan İngiltere'ye Musul dâhil Irak ve Filistin topraklarında manda yönetimi kurma hakkı verilmiştir. Daha önce Fransa'ya bırakılmış olan Musul petrolü, taşınmasında Suriye üzerinden Akdeniz'e ulaşması ve \%25 pay karşılığı şartıyla Fransızlardan alınmıştır (Yalçın, 1998:156). Alınan karar gereğince Suriye'de Fransa mandater devlet haline gelmiştir. Bu gelişme sonucunda Fransa, Faysal'a kendi mandaterliğini kabul etmesi gerektiğini bildiren bir ültimatom vermiştir. Kral Faysal'ın bunu kabul etmemesi üzerine Şam Fransızlar tarafından işgal edilmiş ve bu gelişme Irak Krallı̆̆ı'nın kurulmasına giden yolu açmıştır (Davişa, 2004:37-38).

İngilizler, Irak topraklarını ilk başta kendileri yönetmeyi düşünmüşlerdir. Ancak halkın sert muhalefeti ve Şii öncülüğündeki isyanlarla uğraşmak zorunda kalmışlardır. $\mathrm{Bu}$ nedenle İngilizler Irak'1 yönetmekten 
vazgeçmişler ve Suriye'de sürgüne gönderilen ve Hz. Muhammed'in (S.A.V.) soyundan gelen Faysal'1 23 Ağustos 1921 tarihinde Irak kralı olarak tahta çıkarmışlardır. İngilizler, bu politikaları ile hem Irak'a bütünüyle hâkim olmak, hem de Osmanlıdan doğan halife boşluğunu doldurarak diğer İslam ülkelerine etki etme amacını gütmüşlerdir (Yeşilbursa, 2009:1319).

\section{MUSUL SORUNU}

Musul sorunu, Mondros Mütarekesi ile başlayıp 1926 yılına kadar devam eden ve Türkiye ile İngiltere'yi savaş noktasına getiren bir siyasal gelişmedir (Yalçın,1998:156). Musul sorunu, yeni kurulmuş olan Türkiye Cumhuriyeti'nin dış politikada karşılaştığı en önemli sorunlardan birisi olmuştur. Musul, son Osmanlı Mebuslar Meclisi'nin ilan ettiği Misak-1 Milli kararları çerçevesinde Türk toprakları içerisinde yer almaktaydı. Misak-1 Milli kararları alınırken, Mondros Ateşkes Anlaşması imzalanmıştır. Bu antlaşmaya göre Türk ordusunun elinde bulunan ve etnik olarak Türk olan yerler ayrılmaz bir bütün olarak kabul edilerek, Türkiye sınırları içinde kabul edilmiştir. Ancak 30 Ekim 1918 tarihinde Mondros Ateşkes Antlaşması imzalanırken İngilizler süratli bir şekilde Musul'u ele geçirme çabalarına girişmişlerdir. Bu girişim ateşkes anlaşmasına aykırı bir şekilde yapılmıştır. Çünkü ateşkes hükümlerine göre bölgede bulunan bütün kuvvetlerin oldukları yerde kalmaları gerekmekteydi. Ancak İngilizler, Musul bölgesinde bulunan Ermenilerin, Türk baskısı sonucunda şehri terk etmeye başladıklarını bahane etmiştir. Bu kapsamda da Musul'un boşaltılmaması durumunda ortaya çıkacak çatışmadan Türklerin sorumlu tutulacağını bildirmişlerdir (Gök, 1998:57).

Musul'da bulunan Ali İhsan Paşa durumu İstanbul'a bildirmiştir. Sadrazam Ahmet İzzet Paşa Musul'un tahliye edilmesini ve askerlerin İngiliz komutanın göstereceği mevkiye çekilmesini bildirmiştir (Şahin, 1996:596). Ali İhsan Paşa talimata uygun olarak 10 Kasım 1918 tarihinde Musul'u İngilizlere terk etmiş ve orduyu Nusaybin'e doğru çekmiştir (Özgiray, 1988:131). Bu gelişmelerden sonra İngilizler Musul'u tamamen işgal etmişlerdir. Böylelikle Musul vilayeti, bir bütün olarak İngiliz kontrolüne geçmiştir.

Yukarıda yapılan açıklamalar doğrultusunda Musul, savaş yoluyla işgal edilmemiştir. Mondros Ateşkes Anlatmaşının 7. maddesi ileri sürülerek İngilizler tarafından diplomasi ile işgal edilmiştir. Musul Eyaleti ve buna bağlı olan Kerkük, Süleymaniye ile Erbil sancakları ateşkes hükümlerine ve uluslararası savaş hukukuna aykırı bir şekilde işgal edilmiştir. Musul'un bu şekilde elden çıkmasına neden olan unsurlardan biri de dönemin İstanbul Hükümeti’nin izlemiş olduğu teslimiyetçi siyasettir (Kurtcephe, 1998:6). Musul Sorunu; Mondros Ateşkes Anlaşması ile başlayıp, 1926 yılına kadar çeşitli aşamalardan geçmiş ve yeni kurulmuş olan Türk Devleti'nin başta İngiltere olmak üzere özellikle batılı ülkelerle olan ilişkilerinin temel meselesi olmuştur (Yalçın, 1998:156). Musul meselesi sadece içinde bulunduğu zamanın değil, sonraki dönemlerde de farklı şekillerde Türk dış politikasının gündeminde sürekli olarak yer almış bir unsur haline dönüşmüştür.

Milli Mücadele'nin Atatürk önderliğinde başarılı olması ve işgal kuvvetlerinin Anadolu'dan çıkarılması sonucu Mudanya Ateşkes anlaşması imzalanmıştır. Bu gelişmeler 1şığında işgal devletleriyle daha önce imzalanan ve pratikte hükümsüz hale gelen Sevr Antlaşmasının yerine yeni bir antlaşma yapmak için taraflar İsviçre'nin Lozan kentinde bir araya gelmişlerdir. Kasım 1922 tarihinde başlayan görüşmelerin en önemli başlıklarından birisini Musul sorunu oluşturmuştur. Türkiye açısından Misak-1 Milli sınırları içinde olması nedeniyle Musul, büyük önem taşıyordu. Ancak zengin petrol yataklarına sahip olması, Hindistan yolu için bir güvenlik rolünün bulunması ve ekonomik - stratejik yönleri nedeniyle İngiltere açısından da büyük bir önemi bulunmaktaydı (Yalçın, 1988:160).

İngiltere, konferansta ilk önce Musul sorununu ele almak istemiştir. Bunun altında yatan temel neden, Irak'taki durumun karmaşı hale gelmesi ve zengin petrol kaynakları nedeniyle ABD ve Fransa gibi devletlerin de bu topraklara ilgisinin artmasıdır. 22 Kasım'da yapılan ikili görüşmelerde Türk tarafı Musul'un Türkiye'nin bir parçası olduğunu ve bu nedenle Türkiye'ye iade edilmesi gerektiğini belirtmiştir. İngilizler ise Kral Faysal ile yaptıkları antlaşma doğrultusunda bu coğrafyadaki halk çoğunluğunun Türk olmadığını ileri sürerek Musul'un Irak'ın bir parçası olması gerektiğini iddia etmişlerdir. Yaşanan bu görüş ayrılıkları nedeniyle görüşmeler sonlandırılmıştır. Konferansta İkili görüşmelerden sonuç alınamayınca konunun genel oturumda görüşülmesi kararlaştırılmıştır (Kurtcephe, 1998:12). 23 Ocak 1923 tarihli genel oturumda gündeme gelen Musul Meselesinde İsmet Paşa Türkiye'nin tezlerini ileri sürerken Etnografik, hukuksal, tarihsel, ekonomik, siyasal, askeri ve stratejik noktalar üzerinde durmuştur (Oran, 2008:260).

İsmet İnönü, etnografik açıdan bölge nüfusunun 500.000 kadar olduğunu, bu nüfusun 263.000'inin Kürt, 146.000'inin Türk, 43.000'inin Arap, 18.000'inin Yezidi, 13.000'inin de Gayrimüslim halktan oluştuğunu beyan etmiştir (Oran, 2008:260). İsmet Paşa, Musul vilayetinin çoğunluğunun Türk-Kürt ayrımı yapılmaksızın 
Türk olduğunu ve Anadolu'dan ayrılamayacağını belirtmiştir. Aynı zamanda Türk ve Kürtlerin Arap ve diğer unsurlardan ayrı olarak aynı ırktan geldiği ve Turan kökenli olduklarını İngiliz kaynaklarına (Encyclopedia Britannica'ya) dayandırarak ortaya koymuştur. Böylelikle nüfus bakımından Türk ve Kürtlerin bölgede oluşturdukları çoğunluk bilimsel verilere dayandırılarak ortaya konulmuştur (Kurtcephe, 1998:13).

Hukuksal açıdan ele alınırsa Musul, ateşkesten sonra işgal edilmişti. Bu durum hem uluslararası hukuka, hem de Wilson ilkelerine aykırıydı (Oran, 2008:260). Tarihsel olarak Musul ilk olarak 1055-1056 yıllarında Selçuklu Devletine bağlanmıştır. Bu tarihten itibaren Türkleşen Musul I. Dünya Savaşı sonuna kadar değişik Türk devlet ve beyliklerinin hâkimiyet sahaları içerisinde yer almıştı. Bu bağlamda Musul, Türkler tarafından bir vatan toprağı olarak görülmüştür (Öke, 1995:271).

İsmet Paşa, coğrafi olarak Musul'un, Anadolu'nun bir uzantısı olduğunu belirtmiştir. Musul'u Akdeniz'e bağlayan demir yolları yapılınca burası Irak'tan çok Anadolu'ya bağlı olacaktı. Aynı zamanda ekonomik olarak da Musul'un Diyarbakır'a ve Akdeniz limanlarına bağlı olduğu görüşünü dile getirmiştir. Irak devletine kalan Bağdat ve Basra ekonomik açıdan bu ülkeye yeterliydi. İsmet Paşa bu tezlerini ileri sürdükten sonra konunun Milletler Cemiyeti'ne götürülemeyecek kadar açık olduğunu ifade ederek Musul'da bir referandum yapılmasını teklif etmiştir.

İsmet Paşa'dan sonra söz alan Lord Curzon ise ortaya attı̆ğ tez ile Türk tarafının tezini çürütmeye çalışarak olayı normal seyrinde kaydırmaya çalışmıştır. Bu davranışı ile Musul'u almak istemelerinin petrol nedeniyle olduğu gerçeğini gizlemeye çalışmıştır. Buna göre Lord Curzon, Türk'lerin bölge nüfusunun ancak 1/12'sini oluşturduğunu ve çoğunluğu oluşturan Kürtlerin Türk Kökenli değil, İran kökenli olduğunu ve Araplardan az olan Türklerin ise Osmanlıca yerine Azerbaycan diline yakın bir dil konuştuğunu savunmuştur (Sonyel, 1991:308). Ayrıca kurulan bağımsız Irak Devleti'nin iktisadi anlamda Musul'a ihtiyaç duyduğu gerekçesiyle Kral Faysal ile yapılan anlaşma çerçevesinde Musul'un Irak'ın ayrılmaz bir parçası kabul edildiği belirtilmiştir (Kurtcephe, 1998:7).

İkinci oturum görüşmelerinde ise meselenin iyice çıkmaza girmesi üzerine İsmet Paşa bölgede bir referandum yapılması fikrini öne sürmüştür. Bu teklif yine Lord Curzon tarafından bölge halkının cahil olması ve oy verme alışkanlığının bulunmaması nedeniyle reddedilmiştir (Karacan, 1993:162). Bu kapsamda bölge halkının referandumun amacını anlayamayacağını ifade etmiştir. Fakat Kral Faysal başa geçirildiği zaman meşruiyet kazandırmak amacıyla referandum yaptırıldığg göz ardı edilmemelidir.

Referandum teklifine karşı Lord Curzon meselenin Milletler Cemiyeti'ne havale edilmesini teklif etmiş ve bu teklif İngiltere'nin müttefikleri tarafından da desteklenmiştir. Sonrasında yapılan görüşmelerden hiçbir sonuç alınamamış ve bunun üzerine 4 şubat 1923 tarihinde yeni bir barış tasarısı hazırlayan İngiltere ve müttefikleri barış görüşmelerinin kesilmesi tehdidiyle hazırlanan taslağı Türk Heyeti'ne kabul ettirmeye çalışmışlardır (Yalçın, 1998:166-167).

8 Mart 1923 tarihinde TBMM hazırlanan tasarıya karşı kendi anlaşma tasarısını bildirmiştir. Bunun üzerine 23 Nisan 1923 tarihinde Lozan'da konferansın toplanması kararlaştırılmıştır. Toplanan konferansta Musul Meselesi dahil üzerinde uzlaşılamayan konular sonraki görüşmelere bırakılarak 24 Temmuz 1923 tarihinde Lozan Barış Antlaşması imzalanmıştır. Antlaşmanın III. maddesinin II. fikrasına göre (Bayur, 1973:164-165);
“Türkiye ile Irak arasındaki hudut 9 ay zarfinda Türkiye ve Büyük Britanya arasında Bil itilaf tayin edilecektir. Bu müddet zarfinda iki hükümet arasında bir antlaşma olmadı̆̆ takdirde itilaf cemiyeti akvam meclise arz olunacaktır. Hudut hakkında alınacak karara intizaren kati mukadderatı işbu karara tabi olacak olan arazinin hali hazırdaki vaziyetinde herhangi bir tebeddülü husule getirecek mahiyette askeri veya sair hiçbir harekette bulunulmamasına Türk ve Britanya hükümetleri birbirine karşı taahhüt eder",

hükmü yer almıştır. Lozan görüşmelerinde Misak-1 Milli'nin tam olarak gerçekleşememesinin nedenlerinden biri Türkiye'nin konferansta yalnız kalması ve hemen her konuda müttefiklerin ortak hareket etmesi olarak gösterilebilir. $\mathrm{Bu}$ görüşü savunanlar İngiltere'nin Lozan'a görüşmeler için alanında uzman diplomatları gönderdiğini, Türk Heyeti'nin başında bulunan İsmet Paşa'nın ise asker olması nedeniyle diplomatik alanda başarılı olamadığını ileri sürmektedirler (Gök, 1998:59). Önemli diğer bir neden ise Musul Meselesinin sonraya bırakılmasının hata olduğu görüşüdür. Erzurum Mebusu (milletvekili) Durak Bey; "Musul Meselesinin halini sonraya bırakmak demek, Musul'u kaybetmek demektir" (Armaoğlu, 1998:137), şeklinde ifade etmiştir. Lozan'da başarılı olunamamasına ilişkin diğer bir iddia da Musul meselesinin Milletler Cemiyeti'ne bırakılması kararını aslında Mustafa Kemal Atatürk'ün de savunmuş olmasıdır. Çünkü ona göre Musul'u vermemekte direnen Türkiye'nin, İngiltere ile bir savaşı göze alması gerekir. Oysaki Türkiye'nin o gün içinde bulunduğu 
durum buna olanak vermemektedir. Mustafa Kemal, Musul'un geri alınmasını bir sorun olarak görmemekte, ancak savaşın uzun sürmesi durumunda Türkiye'nin bunu göze alamayacağını savunmaktadır. Günümüzde bile İsmet Paşanın sırf batılılaşma ve İngiltere'yle anlaşma uğruna Musul'u gözden çıkardığı eleştirileri bundan dolayı yapılmaktadır (Oran, 2008:260).

Lozan Antlaşmasından sonra 5 Ekim 1923 tarihinde İngiltere, Türkiye'ye başvurarak Lozan Antlaşmasının III. maddesine dayanarak Musul Konusu ile görüşmelere başlanılmasını talep etmiştir. Talep edilen ikili görüşmeler "Haliç Konferansı" olarak bilinen toplantılarla 19 Mayıs 1924 tarihinde başlamıştır. Konferansta Türk Heyeti'nin başkanlığını TBMM Başkanı Fethi Okyar, İngiltere Heyeti'nin başkanlığını ise Sir Percy Cox yapmıştır. Türk Heyeti görüşmelerde İsmet Paşa'nın tezlerini yinelemiş ve Musul'u Türkiye'ye bırakacak şekilde sınırın çizilmesi gerektiğini öne sürmüştür (Musul-Kerkük ile İlgili Arşiv Belgeleri 1529-1919, 1993). Buna ek olarak Süleymaniye, Kerkük ve Musul'un Türkiye'ye bırakılması durumunda buradaki petrolden İngilizlere ortaklık vermeyi teklif etmiştir. İngiliz Heyeti ise temel sorunun Musul'un geri verilmesi ile ilgili olmadığını, aksine Türkiye ile Irak arasındaki sınırın belirlenmesinden ibaret olduğunu ve Musul'un Irak yönetimine bağlı olması nedeniyle sınırın Musul'un kuzeyinden geçmesi gerektiğini belirtmiştir. Cox, Hakkâri'deki Nasturiler ${ }^{1}$ 'i de bahane ederek Hakkâri'nin üç kazasının (Çölemerik, Beytüşşebap ve Şemdinan) Irak'a verilecek şekilde sınırın çizilmesi gerektiğini belirtmiştir (Kodal, 2005:199). İki heyet kendi görüşlerinde 1srar edince Haliç Konferansı 5 Haziran'da tatil edilmiştir. Görüşmelerin kesilmesinden sonra Türkiye, Nasturîlerin isyanı ${ }^{2}$ yla karşılaşmıştır. Birinci Dünya Savaşı'nda İngilizler tarafından kullanılan bu Hristiyan azınlık, mütareke sonrası kaçtıkları İran'dan alınarak Irak'a İmadiye'ye yerleştirilmiştir. Bu hareketle Türkiye'ye karşı bir tampon bölge oluşturulmak istenmiştir. İngilizler tarafından desteklenen bu isyan kısa sürede bastırılmıştır (Anzerlioğlu, 2000:134).

Haliç Konferansı'nın başarısızlığa uğraması ile birlikte İngilizler, Lozan Antlaşmasının III. maddesi uyarınca sorunu Milletler Cemiyeti’ne götürmek istemiştir. 20 Eylül 1924 tarihinde konu görüşülmeye başlanmış ve Türk tarafı önceki görüşlerinde 1srarcı olmuştur. Türkiye, Musul'da referandum yapılmasını istemiştir. Buna karşın İngiltere sorunun Musul'un geleceği ile ilgili olmadığını, aksine Türkiye-Irak sınırının tespiti olduğunu ve bu nedenle oylama ile çözülemeyeceğini belirtmiştir. Bu hususta sorunun çözümü için komisyon kurulmasını önermiştir (Kurtcephe, 1998:17-18). Milletler Cemiyetinde 30 Eylül 1924 tarihinde bir soruşturma kurulu kurulması ve bu komisyonun Irak'ta incelemede bulunarak Musul halkının görüşlerine başvurması kararlaştırılmıştır (Esin, 1974:350).

Komisyon çalışmaları devam ederken Musul bölgesinde İngiliz-Türk silahlı kuvvetleri arasında mevzi çatışmaları başlamıştır. İngilizler, 9 Ekim 1924 tarihinde Türkiye'ye tehdit niteliğinde verdikleri ültimatomda, Türk kuvvetleri 48 saat içinde İngilizler tarafından kabul edilen sınır hattı gerisine çekilmezlerse zora başvuracaklarını bildirmişlerdir. Bunun temel nedeni, Irak'ın kuzeyinde Nasturiler'in yoğun olarak yaşadıkları bölgede çıkan çatışmalar nedeniyle Türk tarafının saldırgan bir tavır sergilediği iddiasıydı. Nasturiler'in özellikle Hakkâri ve çevresinde bulundukları düşünüldüğünde aslında istenen Türkiye'nin kendi topraklarından çekilmesiydi. Bunun üzerine, Türkiye geçici bir sınır hattının tespiti için Milletler Cemiyeti Meclisine başvurmuştur. Milletler Cemiyeti, Türkler ile İngilizler arasındaki sınır çatışmasını engellemek amacıyla 29 Ekim 1924 tarihinde iki ülke arasında geçici bir sınır (Brüksel Hattı) belirlemiş ve tarafların bu sınıra uymasını tavsiye etmiştir (Öke, 1987:149). İki tarafça kabul edilen öneriye göre Süleymaniye şehri, Irak Krallı̆̆ 1 topraklarında; Hakkâri ve Musul'un kuzeyindeki küçük bir bölüm ise Türk toprakları içerisinde gösterilmiştir (Öke, 1987:149).

Milletler Cemiyeti'nde Musul konusundaki görüşmeler devam ederken 13 Şubat 1925 tarihinde Anadolu'da Şeyh Said (Abdulkadir) isyanı baş göstermişti. Dış ülkelerin destek ve yönlendirmeleri ile Şeyh Said tarafından başlatılan ve Butyanlı, Mestanlı, Tavaslı ile Sivanlı aşiret reislerinin de destek verdiği bu isyan hareketi, cumhuriyetin kuruluşundan itibaren Türk Hükümetine karşı başlatılan ilk ve en kapsamlı Kürt ayaklanmasıdır. 1924 Nasturi ayaklanmasını İngiltere'nin tahrik etmiş olması ve isyanın Musul görüşmeleri sırasında ortaya

1 Nasturî tabiri, V. yüzyılda Hristiyan dünyasında yaşanılan görüş ayrılıkları sonucu ortaya çıkmış bir Hristiyan mezhebi olan Nasturîlik mezhebinin temel ilkelerini ortaya koyan ve aslen Maraşlı olan İstanbul Patriği Nastorious'un adından gelmektedir.

27 Ağustos 1924 tarihinde ayaklanan Nasturîler, Hakkâri valisi ile jandarma kumandanını esir almışlardır. Bu olayda esir edilen Hakkâri Valisi Halil Rıfat Beyin daha sonra verdiği ifadesinde; "Nuhub'dayken iki İngiliz uçağının üzerimizden uçtuğu ve sabahleyin de epey aşă̆ıdan iki uçă̆ın sınırımız dâhilinde dolaştı̆̆ ve bizim esir sıfatı ile Irak'taki Umadiye'ye gönderilmek istenmemiz ve Nasturîler arasında askerî elbiseli ve silâhlı İngiliz askerlerinin görülmesi, Ingilizlerin son günlerde bu canileri hükûmetimiz aleyhine kışkırtmakta olduğuna şüphe bırakmamaktadır”, demiştir (Memiş, 2002:145). 
çıkmış olması bu isyanın da arkasında İngiltere'nin olduğu fikrini çağrıştırmaktadır. Ayaklanma ile uğraşan Türkiye'nin Irak'a askeri müdahale yapma ihtimali zayıflamış ve Musul meselesinde direnmesi zorlaşmıştır (Oran, 2008:264-265). Şeyh Sait isyanı, Musul'un kaybedilmesinin temel nedenleri arasında sayılır. Ancak bu isyan Musul'un kaybedilmesinde tek başına bir neden olmaktan uzaktır. Lozan Konferansı'nın ilk tur görüşmelerinde meselenin ikili görüşmeler kapsamına alınıp kapalı kapılar ardında görüşülmesi, uluslararası konjonktürün yeniden düzenlenme çabaları neticesinde yeni kurulan Türkiye'nin İngiltere ile ilişkilerini geliştirmek istemesi ve ortaya çıkan İtalyan tehlikesi nedeniyle İngiltere'ye en azından diplomatik anlamda muhtaç olunması gibi nedenlerde bu süreçte önemli olumsuz etkenler olarak gösterilir. Bu nedenle Şeyh Sait isyanını, Musul'un kaybedilmesinin tek nedeni olarak görmek yerine, en önemli nedenlerinden birisi olarak görmek gerekmektedir.

Oluşturulan Komisyon 3 aylık kısa bir zaman diliminde gözlemlerini bitirmiş ve bir rapor hazırlamıştır. 16 Temmuz 1925 tarihinde Milletler Cemiyeti'ne, 25 Temmuz'da ise taraf devletlere verilen rapor "Coğrafi ve Etnik Deliller", "Tarihi Deliller", "İktisadi ve Ekonomik Deliller", "Siyasi Deliller", "Stratejik Deliller" ve "Sonuç" kısmı olmak üzere 6 başlıktan oluşmaktaydı (Ayın Tarihi, 1926:439-442).

Coğrafi ve etnik deliller başlığında; hükümetlerin daha önce sunmuş oldukları sınır talepleri belirtilerek bölgenin iklimsel ve coğrafi unsurları hakkında bilgiler verilmiştir. Bölgenin Anadolu ve Irak toprakları içerisinde bulunmasını gerektiren unsurların olduğu belirtilmiştir (Aydın, 2001:97-125). Etnik deliller bölümünde ise nüfusun 500 bin kişilik kısmının Kürtlerden, 167 bin kişilik kısmının Araplardan ve 38 bin kişilik kısmının da Türklerden oluştuğu iddia edilmiştir (Aydın, 2001:128). Raporun tarihi deliller kısmında ise bölgenin uzun bir süre Türk hâkimiyetinde kaldığı ve bazı dönemlerde bölge idarecilerinin Irak coğrafyasına bağlı kişiler arasından atandığı belirtilmiştir (Ayın Tarihi, 1926:440). Raporun iktisadi deliller kısmında da Musul'un Irtak toprakları içerisinde kalmasının uygun olacağı belirtilerek tarafların daha önce üzerinde anlaştıkları Brüksel Hattı'nın uygun bir sınır çizgisi oluşturabileceği ifade edilmiştir (Ayın Tarihi, 1926:440). Yine aynı bölümde Musul ili ile ticarette bulunan yerler belirtilmiş ve en çok ticaretin Bağdat ile yapıldığı iddia edilmiştir (Aydın, 2001:131).

Stratejik Deliller kısmında tarafların daha önce sunmuş oldukları sınır çizgisi önerileri arasından, İngiltere'nin sunmuş olduğu sınır çizgisinin mükemmel bir askeri hudut çizgisi olduğu belirtilmiştir. Siyasi Deliller kısmında ise halkın genelinin Irak Krallığı'na bağlı olmak istediği ve Türk tarafının görüşlerine kayıtsız kaldığg iddia edilmiştir. Raporun sonuç kısmında şu ifadelere yer verilmiştir (Ayın Tarihi, 1926:442);

\begin{abstract}
"Memleket yirmi bes sene kadar tahmin edilen bir muddet zarfinda Cemiyet-i Akvam'in fiili bir mandası altında kalacaktır. Memleketlerin idaresi, adaletin icrası ve mekteplerdeki tedrisat için Kürt ırkına mensup memur istemek ve Kürt lisanının bütün bu subat-ı idariyenin lisan-ı resmisi olmasını talep etmek hususunda Kürtler tarafindan ihzar edilen temenniyat nazar-l i'tibare alınmalıdır. Ĕger Irak ve Ingiltere arasındaki halen cari dört senelik (yani 1922 yllındaki antlasma) muahedenin inkizasinda Cemiyet-i Akvam'ın murakabesi hitama erecekse ve Kürtlere bazı mahalli idare teminatı verilmezse halkın ekseriyetinin Arap hâkimiyetine, Turk hâkimiyetini tercih edeceğine komisyon kanidir"
\end{abstract}

Türk tarafı en iyi seçeneğin referandum olması gerektiğini vurgulamış olması ve bunun uygulanabilir olmasına rağmen bundan özenle kaçınılmıştır. Bu durum da raporun içeriğinde yer alan bilgilerin gerçekle örtüşmemesine ve manüple edilmiş olmasına işaret etmektedir. Milletler Cemiyeti, komisyon raporunu 3 Eylül 1925 tarihinde görüşmeye başlamıştır. Görüşmeler esnasında İngiltere, komisyonun Irak'a bırakılması için öne sürdügü manda süresinin uzatılması ve Kürtlere özerklik verilmesi şartlarını kabul ettiğini, buna karşılık Türkiye ise kararı tanımadığını ve Musul üzerindeki hâkimiyet haklarından vazgeçmediğini bildirmiştir (Kurtcephe, 1998:19). Atatürk bu konudaki görüşlerini şu şekilde ifade etmiştir; "Musul vilâyeti, Türkiye Devleti'nin hudud-u millîyesi dâhilindedir. Buralart anavatandan koparı şuna buna hediye etmek hakkı kimseye ait olamaz. Cemiyet-i Akvam ile bu meselenin ilgisi yoktur” (Atatürk Kültür, Dil ve Tarih Yüksek Kurumu, 2006:459).

Türkiye'nin bu komisyon raporuna itiraz etmesi üzerine Konsey, 19 Eylül 1925 tarihinde Adalet Divanından görüş istemiştir. Divanda, Türkiye'nin karşı çıkmasına rağmen 8 Aralık 1925 tarihinde Milletler Cemiyeti Meclisinin kararı benimsenmiştir. 16 Aralık 1925 tarihinde Soruşturma Komisyonu raporu kabul edilmiştir. Buna göre Brüksel Hattı'nın kuzeyi Türkiye'ye, güneyi ise Irak'a bırakılmıştır (Melek, 1983:50). Ayrıca İngiltere'nin manda rejiminin süresi 25 yıl daha uzatılmıştır. İngiliz Hükümetinin bölgedeki Kürt halkının haklarını koruyacak idari önlemler almasına karar verilmiştir (Öke, 1992:290-297). İngiltere, 13 Ocak 1926 tarihinde Irak ile geçerlilik süresi 25 yıl olan bir antlaşma yaparak Türkiye ile ikili görüşmelere başlamıştır. 
İngiltere ikili görüşmelere başlamak için 20 Ocak 1926 tarihinde İstanbul Büyükelçisi Ronald Lindsay’i görevlendirmiştir. İngiltere, özellikle büyükelçisini görevlendirerek Türk tarafının nabzını yoklamak istemiştir. İngiliz Hükümeti, Milletler Cemiyeti Antlaşması'nın Türkiye aleyhine sonuçlanması nedeniyle Türk tarafının tutumunu kestirememiştir. Çünkü antlaşmadan bir gün sonra yapılan Türk-Rus Saldırmazlık ve Dostluk Antlaşması, Türkiye'nin Musul'a yönelik olarak kuvvet kullanması durumunda Rusya'nın da desteğini alabileceği şeklinde yorumlanmıştır (Öke, 1987:178). Rusya'da aynı şekilde Batılı devletlerle Almanya arasında imzalanan Locarno Antlaşması'nı kendisine yönelik tehdit olarak algılamış ve Türkiye ile yakınlaşmak istemiştir. Ayrıca İngilizlere göre Türkiye antlaşmada hiçbir taviz koparamamıştı. Bu konuda kaybedecekleri bir şey olmadığını düşünerek askeri harekete başvurabilirlerdi. Bu hareket ile ilgili düşüncenin gerçek olup olmadığının araştırılması istenmiştir. Geçen süre içerisinde Türkiye'nin askeri müdahalede bulunma gibi bir amacının olmadığı, hatta baş gösteren İtalya tehdidi ve Rusya'nın güneye inme politikasından dolayı güvenlik önceliği ile hareket ettiği, bu anlamda uluslararası alanda rasyonel adımlar atmaya başladığı ve İngiltere ile olası bir yakınlaşma sürecine önem verdiği belirtilmiştir.

Türkiye Musul sorunu ile uğraşırken, aynı zamanda batılılaşma hedefi doğrultusunda yönünü batıya çevirmiş ve inkılâp hareketleri ile değişim içerisine girmişti. İngiltere'nin batıda güçlü bir simge olması nedeniyle Türkiye'nin İngiltere ile ilgili sorunlarını çözmesi batı ile ilişkilerinde önem arz etmekteydi (Kurtcephe, 1998:20). Bu atmosfer çerçevesinde yapılan görüşmelerde Türk tarafı Sir Lindsay'a taleplerini şu şekilde iletmiştir (Kürkçüoğlu, 1972:315);

\section{"Illk olarak Türkiye, daha önce 17 Aralı 1925 tarihinde Rusya, 18 Şubat 1926 tarihinde ise Fransa ile yapmış olduğu antlaşmanın bir benzerini de İngiltere ile yapmak istemektedir. İkinci olarak Türkiye, Mezopotamya coğrafyasında bulunan Irak Krallı̆̆ı'nın tam bă̆ımsız bir devlet olmasını istemektedir. Üçüncü olarak ise Türkiye, Irak petrollerinin belirli bir hissesinde söz sahibi olmak istemektedir."}

Türk tarafının sunmuş olduğu ilk iki madde derhal reddedilmiş petrol ile ilgili olan kısım için ise İngiliz Hükümetine danışılmış ve taraflar arasında yapılan görüşmeler neticesinde İngiltere'nin 25 yıllık süre zarfinda Irak petrollerinin \%10'luk pay önerisi 30 Mayıs 1926 tarihinde Türkiye tarafından kabul edilmiştir (Öke, 1987:193).

Türkiye ile İngiltere arasındaki sorunların giderilmesinden sonra, 5 Haziran 1926 tarihinde Ankara'da Türkiye, İngiltere ve Irak arasında "Türkiye-Irak Sınırı ve İyi Komşuluk İlişkileri Antlaşması" imzalanmıştır. Ankara Antlaşması genel olarak üç kısımdan oluşmaktadır. Türkiye ile Irak sınırını belirleyen birinci kısımda; söz konusu Brüksel Hattı, Aşuta ve Alamun güneyinde, bu iki yeri birbirine bağlayan yolun Irak topraklarından geçen kesimini Türk toprakları içerisinde bırakmak üzere değiştirilmiştir (Soysal, 1965:310). İkinci kısımdaki başlık kapsamında ise taraflar sınır boylarında eşkıyalığa, yağmacılığa karşı işbirliği içinde olmayı taahhüt etmişlerdir. Son kısımda ise ortak çıkar alanlarını genişletmek amacıyla Irak Hükümeti, antlaşmanın yürürlüğe girmesinden itibaren 25 yıl süreyle Irak Petrollerinden \%10 hisseyi Türkiye tarafına vermeyi taahhüt etmiştir (Soysal, 1965:313-314). Antlaşmaya ekli olarak İngiltere ve Irak yetkili temsilcilerinin Türkiye Dışişleri bakanına verdikleri mektupta, Türkiye'nin bu payını isterse "500 bin sterlin" nakit olarak alabileceği yazılmıştır. Türkiye ise 500 bin sterlin alarak Musul üzerindeki tüm haklarından vazgeçme yolunu seçmemiş, 25 yıl süreyle Irak petrollerinden \%10 pay alma seçeneğini tercih etmiştir (Kısıklı, 1999:526). Türkiye'nin petrol gelirleri üzerinde sahip olduğu imtiyazlar noktasında Irak ile sürekli sorunlar yaşamıştır. Bunun temel nedenleri ise Türkiye'nin hakkının zamanaşımına uğratılmak istenmesi, petrol üretiminin düşük gösterilmesi ve Türkiye'nin süreci iyi yönetememesi olarak gösterilebilir. Ankara Antlaşması ile Musul sorunu Türkiye Aleyhine çözülmüştür. Türkiye'nin Musul'u kaybetmesinin ardındaki sebepler şu şekilde açıklanabilir;

- İlk olarak Birinci Dünya Savaşı Müttefik Devletler lehine sonuçlanmıştı ve Osmanlı devleti, Sevr Antlaşması ile fiilen ortadan kalkmıştı. Savaş sırasında Irak Cephesi içerisinde bulunan Musul, gerek İngiliz kuvvetlerinin üstünlüğü ve gerekse Türklerin diğer cephelerde önemli kayıplar vermeleri nedeniyle Türk hâkimiyetinden çıkmıştı. Bunun sonucu olarak da Musul sorunu ile ilgili olarak yapılan görüşmelerde İngiltere'nin Türkiye'ye karşı diplomatik üstünlüğü ortaya çıkmıştı. Bu durum İngiltere'nin bir bakımdan Irak bölgesindeki askeri kazanımlarını da yansıtmaktaydı.

- İkinci olarak Musul sorunu sadece masa üzerinde diplomatik faaliyetlerin yürütüldügü çerçevede ilerlememiştir. Türkiye aynı zamanda bölgede çıkartılan Nasturi ve Şeyh Sait isyanları ile de uğraşmak zorunda bırakılmıştır. Bu durum Türkiye'nin Musul konusundaki mevcut gücünü olumsuz yönde etkilemiştir. 
- Son olarak Türkiye'nin bağımsızlı̆̆ını kazanmış yeni bir devlet olması ve uluslararası ortamda destek görememesi Türkiye'yi yalnızlaştırmıştır. Artan İtalyan ve Rus tehtidi güvenlik kaygısını ön plana çıkarmıştır. Yaşanan bu durumlar İngilizler ile ilişkileri geliştirme seçeneğini kuvvetlendirmiştir. Yaşanan diğer olumsuzlukların da etkisiyle Musul konusundaki güç ve direnç azalmıştır.

\section{1926-1938 YILLARI ARASINDA TÜRKIYYE - IRAK İLISŞKILLERI}

Musul sorununun çözülmesi ile birlikte 1926-1938 yılları arasındaki dönemde uluslararası alanda yaşanan gelişmeler Türkiye ile Irak arasındaki yakınlaşmanın artmasına neden olmuştur. Bu süreç içerisinde Avrupa merkezli güçlerin Ortadoğu'ya yönelik politikaları Türkiye'nin Irak politikasını belirlemesinde önemli bir rol oynamıştır.

Ankara Antlaşması ile Türkiye ve Irak arasındaki sınır sorunu çözülmüştür. Bunun sonucunda da karşılıklı olarak elçilikler açılmaya başlanmıştır. 16 Ocak 1928 tarihinde Irak Devleti Ankara'da, 21Aralık 1929 tarihinde ise Türkiye, başkent Bağdat'da büyükelçiliklerini açmıştır (Soysal, 1965:306). Irak Krallığı, dış ilişkiler konusunda Milletler Cemiyeti'ne üye olduğu 1932 yılına kadar İngiltere'ye bağımlıydı. Bu nedenle de bağımsız kararlar alamamaktaydı. Mevcut duruma rağmen Kral Faysal Türkiye dâhil Ortadoğu ülkeleri ile yakın ilişkiler içerisinde bulunmuştu. Musul sorununun çözülmesinden sonra en önemli sorun İran ile yaşanan Şattu-l Arap Su Sorunu olmuştu (Sosyal, 1994:3136-3139).

Türkiye ile Irak arasında diplomatik düzeyde başlayan ilişkiler zamanla ileri bir düzeye taşınarak dostluk ve ittifak görüşmeleri çerçevesinde ilerlemiştir. Kral Faysal, Bağdat Büyükelçisi Lütfi Bey vasitasıyla Ankara'y1 ziyaret ederek Atatürk'e saygılarını sunmak istediğini iletmiştir. Fakat bu Türkiye'de hemen karşılık bulmamıştır. 25 Mayıs 1931 tarihinde Kral Faysal, Bağdat Büyükelçiliği vasıtasıyla Kuzey Irak’ta Barzani aşireti ve İngiltere ile sıkıntıları olduğunu iletmiş, bu kapsamda da Ankara'ya ziyarette bulunmak istediğini yinelemiştir. Bu gelişmeler ve talep Türkiye'de karşıllk bulmuştur (Şimşir, 2004:85). 6-7 Temmuz 1931 tarihleri arasında Kral Faysal Türkiye'de özel bir konuk ve kardeş devlet başkanı sıfatı ile ağırlanmıştır. Atatürk bu ziyareti; "Türkiye bütün komşularıyla ve özellikle bölgesel ve uluslararası siyasi ve ekonomik konularda aynı anlayışa sahip Irak ile ilişskileri gelişstirmeyi arzu etmektedir", şeklinde değerlendirmiştir (Bilgin, 2003:219).

Türkiye - Irak ilişkileri Atatürk'ün izlemiş olduğu dostluk ve kardeşlik perspektifinde büyük bir gelişme göstermiştir. Türkiye rehberliğinde işbirliğine dayanan bir siyaset izlenmiştir (Şimşir, 2004:84-85). Irak, pek çok konuda Türkiye'yi örnek model olarak almıştır. Özellikle Türkiye'nin milli iktisat politikası Irak basınında ideal model olarak kamuoyuna sunulmuştur. Türkiye ile Irak arasında oluşan dostluk havası taraflar arasında ayrıcalıklı bir anlaşma yapma imkânını da beraberinde getirmiştir. Türkiye ile Irak arasında, 9-10 Ocak 1932 tarihlerinde, "İade-i Mücrimin Muahedenamesi", "İkamet Mukavelesi" ve "Ticaret Muahedenamesi" olmak üzere üç farklı alanda antlaşma imzalanmıştır. İade-i Mücrimin Antlaşması'na göre, her iki devlet makamı da barış ve huzurun temini ile suçluların iadesini tanzim etmeyi karşılıklı olarak taahhüt etmişlerdir (Canatan, 1996:36-43). On sekiz maddeden oluşan "İade-i Mücrimin Antlaşması'na göre ise taraflar, suçluların iadesi konusunda uzlaşmaya varmışlardır. Ayrıca bu konuda, istisnai durumlar da belirtilmiştir ${ }^{3}$. İkamet Mukavelesi Antlaşması, ticari hükümler içeren bir anlaşma özelliği taşımaktadır. Bu antlaşmaya göre taraf devletlere mensup vatandaşların ve şirketlerin, diğer devlet arazisinde ikamet edebilmesi ve ticaret yapabilmesine hak tanınmaktaydı (Canatan, 1996:36-45). Ticaret Muahedenamesi antlaşma hükümlerine göre taraf devletler arasında ticari ilişkilerin canlandırılması esas alınmıştır (Canatan, 1996:36-48).

1926 yılında Türkiye ile Irak arasında gerçekleştirilen Sınır ve İyi Komşuluk İlişkileri Antlaşması'nın süresinin uzatılmasına ilişkin olarak taraflar 1936 yılında karşılıklı nota alışverişinde bulunmuşlardır. Karş11ıklı nota teatilerinin ardından 1926 yılından imzalanan Ankara Antlaşmasının uzatılması kararlaştırılmıştır. Bu antlaşma Sadabat Paktına giden süreçte aşılan önemli bir adım olmuştur.

3 "Suçluların İadesi" konusunda tarafların, isteklerinin kabul edilemeyeceğini belirten 4. maddede yer alan istisnai durumlar su şekildedir: Siyasi suçlar; Askeri suçlar; Matbuat suçları; Şahsın üzerinde takip edilebilen ve işbu sahsın feragat etmesiyle takibine nihayet verilmesi gereken suçlar; bulunduğu ülke kanunlarına göre zaman asımına uğramış olan suçlar; bulunduğu ülkede hali hazırda davasının devam ettiği veya hükmünün verildiği suçlar; talep olunan devletin makamının suç hakkında hüküm verme yetkisine sahip olduğu suçlar; üçüncü bir devletin müdahil olduğu suçlar (Canatan, 1996:37-38). 


\section{SADABAT PAKTI}

1930'lu yıllarda I. Dünya Savaşı sonrası oluşturulan düzenden rahatsız olan revizyonist ve düzeni korumaya çalışan anti revizyonist ülkeler Avrupa'da bölünme içerisine girmişlerdir. Özellikle İtalya ve Almanya gibi revizyonist ülkelerin güçlenmeye başlaması İngiltere, Fransa ve Türkiye gibi statükodan yana olan devletlerde tedirginlik oluşturmaya başlamıştır. Bu çerçevede Türkiye, İtalya tehdidine karşı ilk olarak Yunanistan, Yugoslavya ve Romanya ile birlikte 1934 yılında Balkan Antantı'nı kurmuştur. İtalya'nın Habeşistan'ı İlhakı Sadabat Paktı'nın imzalanmasında önemli bir etken olmuştur. Mussolini yönetimindeki İtalya'nın 1934 y1lında II. Beş Yıllık Faşist Kongresi'nde Asya toprakları üzerindeki taleplerini açıklaması ve 1935 yılında Milletler Cemiyeti hükümlerine aykırı olarak Habeşistan'ı ilhak etmesi Türkiye açısından Ortadoğu ülkeleri ile Balkan Antantı'na benzer bir antlaşmanın yapılması zorunluluğunu ortaya çıkarmıştır. Bu duruma yönelik ilk girişim 1394 Haziran'ında İran Şahı Rıza Pehlevi’nin Türkiye ziyareti sırasında gündeme gelmiştir (Gönlübol ve Sar, 1977:103-113).

Türkiye ile Ortadoğu devletleri arasında bir pakt kurulmasına yönelik olarak yaşanan ikinci gelişme Cenevre'de gerçekleşmiştir. Türkiye, İran ve Irak arasında 3 Ekim 1935 tarihinde "Ortak Dayanışma Paktı" parafe edilmiştir (Koçsoy, 1991:21). Fakat bu pakt hemen gerçekleşmemiştir. İran ile Irak arasındaki Şattu-l Arap Su Sorunu ${ }^{4}$ nun çözülmesi beklenmiştir. İran ile Irak arasındaki sorun 4 Temmuz 1937 yılında yapılan anlaşma ile son bulmuş (Canatan, 1996:57) ve paktın kurulmasına yönelik gelişmeler devam ettirilmiştir.

İran ile Irak arasındaki meselenin çözülmesi ile birlikte 8 Temmuz 1937 tarihinde Türkiye'yi temsilen Tevfik Rüştü Aras, Irak’1 temsilen Dışişleri Bakanı Naci El Asil, Afganistan'1 temsilen Dışişleri Bakanı Serdar Fevzi Muhammed, Tahran'daki Sadabad Sarayı'nda paktı imzalamışlardır (Soysal, 1965:582-583).

On maddeden oluşan, saldırmazlık ve dostluk içeriğinde imzalanan Sadâbat Paktı, Ortadoğu ülkeleri arasında imzalanan antiemperyalist pakt olarak ortaya çıkmıştır. Birinci maddeye göre imzacı ülkeler birbirlerinin içişlerine karışmama konusunda söz veriyorlardı. İkinci madde ile üye ülkelerin sınırlarının güvenliği ve saldırmazlığı benimseniyordu. Üçüncü madde ise, uluslararası konularda imzacı ülkelerin birbirlerine danışacakları belirtiliyordu. Dördüncü maddede üye ülkelerin birbirine saldırmayacaklarına dair kesin bir hüküm getiriliyordu. Beş ve altıncı maddelerde ise üye ülkelerden birisinin diğer ülkelere saldırması durumunda diğer ülkelerin antlaşmadan çekilebileceği açıkça belirtiliyordu.

Sadâbat Paktına göre, üyelerden herhangi birisinin diğerine tecavüzü sırasında mağdur olan ülkenin sorunu Milletler Cemiyetine götürebileceği belirtiliyordu. Yedinci maddeye göre ise, taraf ülkelerinden her birisi kendi sınırları içerisinde diğer ülkelerin yönetimlerine karşı silahlı örgütlenmelere izin vermeyeceği ve etnik unsurları birbirine karşı kullanmayacağı hüküm altına alınıyordu. Sekizinci madde taraflar arasındaki sorunların barışçıl yollarla çözümleneceğini belirtiyordu. Dokuzuncu maddede antlaşmanın Milletler Cemiyeti esasları dâhilinde yorumlanacağı vurgulanıyordu. Onuncu maddede antlaşmanın beş yıl için yapıldığı, taraflardan her hangi birisinin itirazı olmaması durumunda her beş senede bir antlaşmanın kendiliğinden yenileneceği açıklanıyordu. Antlaşmanın ayrıca Milletler Cemiyeti tarafından onaylanması da kabul edilmiştir. Antlaşma sonrasında bir protokol imzalanarak Sadâbat Paktı'nı yürütmek üzere bir komisyon seçilerek bu konuda görevlendirilmiştir (Çeçen, 2006:318).

Pakta göre antlaşma 5 yıl yürürlükte kalacaktı. Paktı imzalayan taraf devletler, aralarındaki dostluk münasebetlerini devam ettirmeyi, Milletler Cemiyeti ve Briand Kellogg Paktı 'na bağlı kalmayı, birbirlerinin içişlerine karışmamayı, ortak sınırlarına saygı göstermeyi, ortak çıkarları ilgilendiren meselelerde birbirlerine

4 Irak, Osmanlı İmparatorluğunun bir vilayeti iken 1913 İstanbul Protokolüne göre saptanan ayrım çizgisinin haksız olduğunu; bunun, İran kıyısından değil -modern hukuk gereği-“Talveg” kuralına (sınırın akarsu yatağının en derin yerini birleştiren çizgiye göre belirlenmesini) göre yapılması gerektiğini ileri sürüyordu.

5 Briand- Kellogg Paktı 27 Ağustos 1928 tarihinde imzalanmıştır. Amerika ile Fransa arasında müzakere edilen bu daimi dostluk anlaşmasının, Amerika'nın isteği üzerine çok taraflı bir anlaşmaya dönüştürülmesinden doğmuş idi. Anlaşmaya göre buna imzalarını koymuş olan devletler, milletler arası anlaşmazlıkların çözülmesi için savaştan vazgeçiyorlar. Karşılıklı ilişkilerde savaşı milli politika aleti yapmamayı ve içeriği ne olursa olsun aralarında çıkacak herhangi bir anlaşmazlığı barış yoluyla çözeceklerini taahhüt ediyorlardı. Paris’te imzalanan pakta ABD, Fransa, Japonya, Birleşik Krallık, Almanya, Belçika, Çekoslovakya ve Romanya katılmıştır. 
danışmayı ve birbirlerine karsı herhangi bir saldırı hareketine dayalı girişime başvurmayacaklarını taahhüt etmişlerdi (Armaoğlu, 1983:347).

Sadabad Paktı, Türkiye'nin I. Dünya Savaşı sonrasında Avrupa'da güçlenmeye başlayan Faşizm ve Nazizm ideolojileri ile bunların yayılmacı politikalarına karşı caydırıcı bir blok oluşturmayı amaçlamıştır. Güvenlik kaygılarıyla oluşturulan Balkan Paktı'nı, aynı kaygıyla oluşturulan Sadabad Paktı sürdürmüştür. Fakat II. Dünya Savaşı'nın çıkması ile bu pakt dağılmıştır. Buna rağmen Sadabad Paktı, Türkiye'nin doğu sınırlarını oluşturan komşularıyla sınır anlaşmazlıklarının da çözümüne katkı sağlamıştır.

\section{SONUÇ}

Atatürk dönemi Türkiye-Irak ilişkileri, belli bir dönem zarfında iki bağımsız ülkenin birbiriyle karşılıklı ilişkisi çerçevesinde gelişmemiştir. Çünkü Irak'ın Osmanlı Devleti'nden ayrılışından 1932 yılında Milletler Cemiyeti’ne üye olmasına kadar geçen sürede Türkiye-Irak ilişkileri, Musul Sorunu nedeniyle Türkiye-İngiltere ilişkileri şeklinde gelişmiştir. Musul Sorunu, iki ülke arasındaki ilişkilerin gerilmesine ve hatta iki ülke arasında savaş ihtimalinin ortaya çıkmasına neden olabilmiştir.

Musul sorunu çerçevesinde bölge, İngiltere açısından Hindistan yolunun güvenliği bağlamında stratejik bir öneme sahipti. Petrol noktasında ise İngiltere açısından büyük bir ekonomik önemi bulunmaktaydı. Aslında yerel bir sorun olan Musul sorunu, sahip olduğu stratejik önemi nedeniyle uluslararası ölçekte bir sorun haline gelmiştir. Atatürk döneminde Musul sorunu önce Lozan'da, sonrasinda ise Milletler Cemiyeti'nde görüşülmüsstür. Ancak yeni kurulan Türkiye Cumhuriyeti Musul sorununun çözümü sürecinde Nasturi ve Şeyh Sait Ayaklanmaları ile uğraştırılarak bir yandan askeri anlamda etkisizleştirilmiş, diğer yandan da uluslararası arenada diplomatik açıdan yalnız bırakılmıştır. Bu gelişmeler Musul sorununda başarısız olunmasına neden olmuştur. İngiltere ile ilişkilerin normalleştirilerek dış politikada hedefin batı olarak belirlenmesinin de bu sonuç üzerinde etkileri bulunmaktadır.

Musul, 12 Ocak 1920'de Misak-1 Milli'ye dâhil edilmiştir. Fakat Kurtuluş savaşı'nın devam ettiği süreçte, milliyetçiler açısından Anadolu'nun diğer bölgelerine nazaran acil olarak kurtarılması gereken bir bölge olarak ele alınmamıştır. Lozan Konferansı'nın başlamasıyla birlikte askeri yöntemlerden vazgeçip diplomasi ile sorunları çözmek Türkiye için daha uygun görünmüştür. Çünkü İstanbul ve Boğazlar'ın müttefiklerin işgali altında olduğu bir ortamda savaşa girmek Türkiye açısından riskli bir durum arz etmekteydi. Bu çerçevede Musul vilayetinin Lozan Konferansı sonrasında kaybedildiği argümanları yerine Lozan Konferansı ile başlayan süreçte kaybedildiği argümanlarına yoğunlaşmak esasen daha sağlıklı olacaktır.

İkinci Dünya Savaşı öncesinde yaşanan uluslararası ortamdaki belirsizlikler ki özellikle İtalya ve Almanya'nın revizyonist politikaları Türkiye-Irak arasında yakınlaşmaya neden olmuştur. Bu durum ülkeler arasında mevcut olan sorunların ileriye ötelenmesini sağlamış ve ülkeler arasında çözüm sürecini zorunlu kılmıştır. Ortaya çıkan bu atmosfer Sadabad Paktı'nın imzalanması ile sonuçlanmıştır. Sadabat Paktı, beklenen sonuçları ortaya çıkaramamış olsa da Balkan Antantına benzer bir biçimde Türkiye'nin bölgesel bir aktör olabilmesi açısından dış politikada yaşanmış önemli bir gelişmedir.

Devletler iç ve dış politikaları ile diplomatik ilişkilerinde uzun vadeli bir perspektif ile hareket ederler. Yerel, bölgesel ve hatta küresel gelişmeler ile de politika ve uygulamalarını revize edip, yeni hareket alanları oluştururlar. $\mathrm{Bu}$ bağlamda Türkiye'nin uluslararası ilişkiler ve diplomatik hamlelerinde öncelikli olarak komşuları ile etkin bir işbirliği içerisinde olması büyük bir önem arz etmektedir. Bu ilişkilerin kuvvetlenmesi ve olumlu anlamda evrilmesi ise geçmiş birikimler ve yeni gelişmeleri doğru bir şekilde okuyarak, uygun manevra kabiliyeti ile mümkün olmaktadır. Bu nedenle Türkiye'nin başta güvenlik olmak üzere ekonomik ve sosyal anlamda önemli bir sınır komşusu olan Irak ile olan ilişkileri her iki devletin de kuruluş dönemleri esas alınarak ele alınmıştır. Bu ilişkilerin başlangıç ve seyrindeki temel dinamikler nedenleri ve sonuçları ile ortaya konulmuştur. Ancak çalışmanın kapsamı nedeniyle konu Atatürk dönemi ile sınırlı tutulmuştur. Bu dönemin devamı niteliğindeki tarihsel sürecin günümüze kadar olan kısımlarının ayrı çalışmalarda ele alınması konunun tüm yönleri ile bir bütünlük oluşturması açısından faydalı olacağı düşünülmektedir. 


\section{KAYNAKÇA}

ANZERLİOĞLU, Yonca (2000), Nasturiler, Tamga Yayıncılık, Ankara.

ARMAOĞLU, Fahir (1983), 20. Yüzyıl Siyasi Tarihi: 1914 - 1980, Turkiye İş Bankası Kültür Yayınları, Ankara, Cilt.1.

ARMAOĞLU, Fahir (1998), Lozan Konferansı ve Musul Sorunu: Misak-ı Milli ve Türk Dış Politikasında Musul, Atatürk Araştırma Merkezi Yayını, Ankara.

ATATÜRK ARAŞTIRMA MERKEZİ (2002), Türkiye Cumhuriyet Tarihi II, Atatürk Araştırma Merkezi Yayınları, Ankara.

ATATÜRK KÜLTÜR, DİL VE TARİH YÜKSEK KURUMU (2006), Atatürk’ün Söylev ve Demeçleri I-III, Atatürk Kültür, Dil ve Tarih Yüksek Kurumu Yayınları, Ankara.

AYDIN, Mesut (2001), Türkiye ve Irak Hudûdu Mes'elesi, ASAM Yayınları, İstanbul.

AYIN TARİHI (1926), “Musul Tahkîk Komisyonu'nun Cemiyet-i Akvâm'a Vermiş Olduğu Rapor” (1926), Ayın Tarihi Dergisi, Ankara, S.5(17), ss.315-445.

BAYUR, Yusuf Hikmet (1973), Türkiye Devletinin Dış Siyasası, Türk Tarik Kurumu Yayını, Ankara.

BİLGIN, Mustafa Sitk1 (2003), “Türk Irak İlişkilerinin Tarihsel Boyutu (1534-2002)”, Irak Krizi: 2002-2003 (Der. Umit Ozdağ, Sedat Laciner, Serhat Erkmen), Avrasya Stratejik Arastırma Merkezi Yayınları., Ankara, ss.215-237.

CANATAN, Yaşar (1996), Turkiye-Irak Munasebetleri (1926-1958), T. C. Kültür Bakanlığı Yayınları, Ankara.

ÇEÇEN, Anıl (2006), Türkiye'nin B planı: Merkezi Devletler Birliği (MEDEB), Toplumsal Dönüşüm Yayınları, İstanbul.

DAVIŞA, Adid (2004), Arap Milliyetçiliği: Zaferden Umutsuzluğa (Çev. Lütfi Yalçın), Literatür Yayıncılık, İstanbul.

DURGUN, Şenol (2013), Modernleşme ve Siyaset, A Kitap Yayınları, Ankara, 2. Baskı.

ESIN, Necmettin (1974), “Irak Türkleri ve Musul Meselesi”, Türk Kültürü Dergisi, S.139-141, ss.346-352.

GÖK, Dursun (1998), “1924 Türk Basınında Musul Meselesi”, Misak-ı Millî ve Türk Dış Politikasında Musul, Kerkük ve Erbil Meselesi Sempozyumu Bildiriler Kitabı, Atatürk Kültür - Dil ve Tarih Yüksek Kurumu Atatürk Araştırma Merkezi Yayını, Ankara, ss.57-71.

GÖNLÜBOL, Mehmet ve SAR, Cem (1977), Olaylarla Türk Dış Politikası (1919-1973), Ankara Üniversitesi Siyasal Bilgiler Fakültesi Yayınları, Ankara.

GÖNLÜBOL, Mehmet ve SAR, Cem (1997), Atatürk ve Türkiyenin Dış Politikası (1919-1938), Atatürk Kültür Dil ve Tarih Yüksek Kurumu Yayını, Ankara.

KARACAN, Ali Naci (1993), Lozan Konferansı ve İsmet Paşa, Bilgi Yayınevi, Ankara.

KISIKLI, Emine (1999), "Yeni Gelişmelerin Işı̆̆ında Geçmişten Günümüze Musul Meselesi”, Ankara Üniversitesi Türk İnkılâp Tarihi Enstitüsü Atatürk Yolu Dergisi, S.6(24), ss.487-526.

KOCAOĞLU, Mehmet (1995), Uluslararası İlişkiler Işıı̆ında Ortadoğu, GENKUR Yayınları, Ankara.

KODAL, Tahir (2005), Paylaşılamayan Toprak: Türk Basınına Göre (1923-1926) Musul Meselesi, Yeditepe Yayınevi, İstanbul.

KOLOĞLU, Orhan (1994), Gazi'nin Çağında İslam Dünyası, Boyut Yayınları, İstanbul.

KÖSOĞLU, Nevzat (2000), Türk Milliyetçiliği ve Osmanlı, Ötüken Yayınları, İstanbul, 3. Bask1.

KURAT, Yuluğ Tekin (1975), “Elli Yıllık Cumhuriyetin Dış Politikası 1923-1973”, Belleten Dergisi, S.39(154), ss.265-285.

KURTCEPHE, İsrafil (1998), Atatürk Dönemi Türk Dış Politikasında Musul Sorunu, Kara Harp Okulu Basım Evi, Ankara. 
KÜRKÇÜOĞLU, Ömer E. (1972), “Türkiye-Irak İlişkilerinde Son Gelişmeler”, Ankara Üniversitesi Siyasal Bilgiler Fakültesi Dergisi, S.27(4), ss.247-253.

MELEK, Kemal (1983), İngiliz Belgeleriyle Musul Sorunu: 1890-1926, Üçdal Neşriyat, İstanbul.

MEMIŞ, Ekrem (2002), Kaynayan Kazan: Ortadoğu (Geçmişten Günümüze Ortadoğu Sorunları ve Çözüm Yolları), Çizgi Kitabevi, Konya.

ORAN, Baskın (2008), Türk Dış Politikası, İletişim Yayınları, İstanbul, Cilt.1.

ÖKE, Mim Kemal (1987), Musul Meselesi Kronolojisi: 1918-1926, Türk Dünyası Araştırmaları Vakfı Yayını, İstanbul.

ÖKE, Mim Kemal (1992), Musul ve Kürdistan Sorunu 1918-1926, Türk Kültürünü Araştırma Enstitüsü Yayın1, Ankara.

ÖKE, Mim Kemal (1995), Musul - Kürdistan Sorunu (1918-1926), İz Yayayınları, İstanbul.

ÖZGIRAY, Ahmet (1988), “Türkiye-İngiltere Münasebetleri ve Musul Meselesi (1924-1930),, Türk Kültürü Dergisi, S.26(299), ss.1-15.

SARIHAN, Zeki (1993), Kurtuluş Savaşı Günlüğü: Mondros’tan Erzurum Kongresi’ne (30 Ekim 1918-22 Temmuz 1919), Türk Tarih Kurumu Yayınları, Ankara, Cilt.1.

SONYEL, Salahi R. (1991), Türk Kurtuluş Savaşı ve Dış Politika II, Türk Tarih Kurumu Yayınları, Ankara.

SOYSAL, İsmail (1965), Türkiye’nin Dış Münasebetleriyle İlgili Başlıca Siyasî Andlaşmaları, Türk Tarih Kurumu Basımevi, Ankara.

SOYSAL, İsmail (1994), “1937 Sadabat Pakti”, X. Turk Tarih Kongresi Bildiriler Kitabı, Türk Tarih Kurumu Yayınları, Ankara, Cilt.VI, ss.3136-3139.

ŞAHIN, F. Şayan (1996), “Musul'un İşgali ve Ali İhsan Paşa”, Türk Kültürü Dergisi, S.34(402), ss.595-601.

ŞAHIN, İsmail, ŞAHİN, Cemile ve YÜCE, Samet (2014), “Birinci Dünya Savaşı Sonrası İngiltere'nin Irak'ta Devlet Kurma Çabaları", Gazi Akademik Bakış Dergisi, S.8(15), ss.105-132.

ŞİMŞİR, Bilal N. (2004), Türk - Irak İlişkilerinde Türkmenler, Bilgi Yayınevi, Ankara.

T.C. BAŞBAKANLIK ARŞIVLERİ GENEL MÜDÜRLÜĞÜ (1993), Musul - Kerkük İle İlgili Arşiv Belgeleri (1525-1919), T.C. Başbakanlık Arşivleri Genel Müdürlüğü Osmanlı Arşivi Daire Başkanlığı Yayın1, Ankara.

YALÇIN, Semih (1998), "Misak-ı Milli ve Lozan Barış Konferansı Belgelerinde Musul Meselesi", Misak-ı Milli ve Türk Dış Politikası'nda Musul, Kerkük ve Erbil Meselesi Sempozyumu Bildiriler Kitabı, Atatürk Araştırma Merkezi Yayını, Ankara, ss.155-175.

YAPP, Malcolm (1991), The Near East Since the First World War, Longman, London (UK).

YEŞILBURSA, Behçet Kemal (2009), “Geçmişten Günümüze Irak Meselesi”, Gazi Eğitim Fakültesi Dergisi, S.29(Özel Say1 II), ss.1315-1343. 